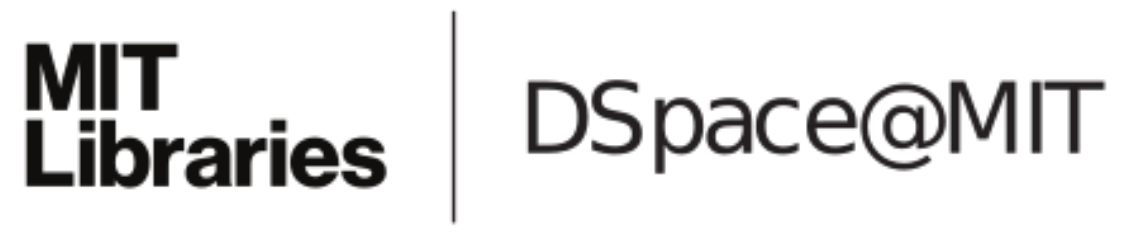

\author{
MIT Open Access Articles
}

Compound Interest Corrected: The Imaginative Mathematics of the Financial Future in Early Modern England

The MIT Faculty has made this article openly available. Please share how this access benefits you. Your story matters.

Citation: Deringer, William. "Compound Interest Corrected:The Imaginative Mathematics of the FinancialFuture in Early Modern England." Osiris (Bruges, Belgium) 33 (2018): 109-129 (C) 2019 The Author

As Published: $10.1086 / 699236$

Publisher: University of Chicago Press

Persistent URL: https://hdl.handle.net/1721.1/124565

Version: Final published version: final published article, as it appeared in a journal, conference proceedings, or other formally published context

Terms of Use: Article is made available in accordance with the publisher's policy and may be subject to US copyright law. Please refer to the publisher's site for terms of use. 


\title{
Compound Interest Corrected: The Imaginative Mathematics of the Financial Future in Early Modern England
}

\author{
by William Deringer*
}

\begin{abstract}
What is money in the future worth today? In the seventeenth century, questions about the "present value" of future wealth became matters of practical concern, as businesspeople and governments deployed future-oriented financial technologies like mortgages, bonds, and annuities. Those questions also attracted the attention of mathematicians. This essay examines the excursions two English mathematicians, the indefatigable mathematical gossip John Collins (1625-83) and the lesser-known Thomas Watkins (fl. 1710s-20s), made into the mathematics of financial time. In capitalist practice today, present-value problems are invariably dealt with using a single technique, compound-interest discounting, which has become deeply embedded in commercial, governmental, and legal infrastructures. Yet, for early modern thinkers, the question of how best to calculate the financial future was an open question. Both Collins and Watkins explored imaginative alternatives to what would become the compound-interest orthodoxy. With help from his network of correspondents, Collins explored simple-interest discounting, which provoked thorny mathematical questions about harmonic series and hyperbolic curves; Watkins crafted multiple mathematical techniques for "correcting" the compound-interest approach to the financial future. Though both projects proved abortive, examining those forgone futures enables us to examine the development of a key element of capitalistic rationality before it became "black-boxed."
\end{abstract}

Among the earliest surviving pieces of correspondence written by a young Isaac Newton are a series of three letters written in January and February 1670 to John Collins, an accountant, sometime government clerk, and mathematics instructor who was also the era's most enthusiastic dealer in mathematical gossip. ${ }^{1}$ The two had met in

\footnotetext{
* Program in Science, Technology, and Society, Massachusetts Institute of Technology, 77 Massachusetts Avenue, E51-188, Cambridge, MA 02139; deringer@mit.edu.

I would like to thank all of the participants in the June 2016 Osiris workshop for their thoughts on an early draft of this essay. I would especially like to thank my coeditors, Lukas Rieppel and Eugenia Lean; the Osiris general editors, Suman Seth and Patrick McCray; and two anonymous reviewers for their thoughtful comments on the manuscript. I would also like to thank Katherine Marshall and the staff at the Royal Society for assistance with images.

${ }^{1}$ Isaac Newton to John Collins, 19 January 1669/70, MS Add. 9597/2/18/1, Cambridge University Library (hereafter cited as "Camb. UL"); Newton to Collins, 6 February 1669/70, MS Add. 9597/2/ 18/2, Camb. UL; Newton to Collins, 18 February 1669/70, MS Add. 9597/2/18/5, Camb. UL. These

- 2018 by The History of Science Society. All rights reserved. 0369-7827/11/2018-0006\$10.00
}

OSIRIS 2018, $33: 109-129$ 
November or December of the previous year, and Collins, clearly impressed by his new associate's talents, passed along some problems in algebra he was eager to see solved. These letters have piqued the interest of Newton scholars and historians of mathematics, both for their mathematical content - they contained creative work on infinite series and on approximating solutions to equations and initiated a dialogue that ultimately inspired Newton's Universal Arithmetick - and because those letters marked one of the first times the publicity-shy Newton circulated mathematical work to a larger community. ${ }^{2}$ But one crucial feature of those letters has not garnered much notice: they were talking about finance.

In particular, the two were discussing mathematical problems that arose concerning annuities, a kind of financial instrument that promises to pay the owner a recurring income over some future period. The question at hand in Newton's second letter was indicative. Consider an annuity that promised the owner $£ 100$ every year for thirty-one years. Imagine that the owner of that annuity had purchased it by paying $£ 1,200$ up front. What interest rate, assuming compound interest, was the owner effectively making on the original $£ 1,200$ laid out? Using logarithms, Newton constructed a formula to estimate the answer within a few pence- 7.43 percent in the particular case in question. Newton's first letter had involved calculating the "present value" of an annuity using a technique called simple-interest discounting, an even more vexing problem closely related to finding the area under a hyperbola (on which more to come). These questions were not merely of academic interest. They had significant commercial utility, as finding more accurate and efficient computational methods for dealing with annuities promised to streamline many common financial transactions. But they also hold a deeper interest for historians of science and capitalism, one that goes beyond either their mathematical ingenuity or financial utility. Within them lay profound, unsettled questions about economic value and future time that would have serious consequences for economic practice and culture in ensuing centuries.

The exchange between Newton and Collins was hardly an isolated occurrence, either. During the period from roughly 1660 to 1720 , several British "men of science" turned their attention to what could be called the mathematics of financial time. These included several members of the new Royal Society of London, ranging from relatively obscure figures, like Collins (1625-83) and Thomas Watkins (fl. 1710s20s) - the two main characters in this essay - to far more eminent ones, like Edmund Halley, James Gregory, and of course Newton. ${ }^{3}$ Those mathematicians became interested in an array of problems related to debt, interest, and time-dependent financial transactions like annuities and mortgages. These problems arose in numerous areas of commercial life, from loans to land transactions to the dealings that took place in London's "Exchange Alley." They were increasingly a matter of political concern as well, as Britain's government came to rely increasingly on long-term public debt to

\footnotetext{
and other letters written by Newton are available online through the Newton Project, http://www .newtonproject.ox.ac.uk/ (accessed 16 April 2018).

${ }^{2}$ Richard Westfall, Never at Rest: A Biography of Isaac Newton (Cambridge, 1980), 222-6; Helena Pycior, Symbols, Impossible Numbers, and Geometric Entanglements: British Algebra through the Commentaries on Newton's "Universal Arithmetick" (Cambridge, 1997), 177.

${ }^{3}$ For Halley's contribution, see "An Estimate of the Degrees of the Mortality of Mankind, Drawn from Curious Tables of the Births and Funerals at the City of Breslau; With an Attempt to Ascertain the Price of Annuities upon Lives," Phil. Trans. 17 (1693): 596-610.
} 
fund state activities, especially after $1688 .{ }^{4}$ Implicit in all of these practical mathematical problems was the fundamental question of how to understand - and how to calculate - the relationship between the economic present and the economic future.

From a historical perspective, there is nothing especially remarkable about elite mathematical thinkers exploring questions that arose in commercial settings - one can find countless examples, from al-Khwārizmī (ca. 780-850) to Leonardo of Pisa ("Fibonacci," ca. 1170-1250) to Benoit Mandelbrot (1924-2010). What is most remarkable about the financial-mathematical excursions embarked upon by these Royal Society calculators was the questions they explored and the possibilities they imagined, and what their mathematical explorations can tell us about the economic moment in which they lived. In short, they were using mathematics to explore the economic future - indeed, to imagine an array of different possible economic futures, many of which ultimately did not come to pass. In his epistolary exchange with Newton, and many other mathematicians besides, John Collins was actually experimenting with two very different approaches to putting a price on the future. In the beginning of the next century, Thomas Watkins published a paper laying out some half dozen different approaches. The shape of the financial future was yet to be determined; for adventurous mathematical thinkers like Collins and Watkins, it was a research question.

It would not remain such an open question for long. By about 1800, most of the problems about value and time that these early modern mathematicians were exploring would no longer seem especially problematic. By that point, a single dominant paradigm had emerged for dealing with all such temporal calculations, an approach we can call compound-interest discounting. That technique used the exponential logic of compound interest as the essential means of translating between the present and the future. In the ensuing centuries, that compound-interest technique would be inserted into countless economic practices: the valuation of financial instruments (bonds, stocks, futures), real estate transactions, insurance, retirement planning, firms' capital budgeting decisions, economic modeling, governmental cost-benefit analysis - even climate-change planning. Nearly any specialized domain of economic activity that involves a temporal element relies on compound-interest discounting in some way. ${ }^{5}$

To use a classic formulation from science and technology studies (STS), compoundinterest discounting would become a quintessential black box, so deeply embedded in

\footnotetext{
${ }^{4}$ For an introduction to practical financial calculations and financial texts in the period, see Natasha Glaisyer, "Calculating Credibility: Print Culture, Trust and Economic Figures in Early EighteenthCentury England," Econ. Hist. Rev. 60 (2007): 685-711. On the broader financial context in the period, see P. G. M. Dickson, The Financial Revolution in England: A Study in the Development of Public Credit (London, 1967); John Brewer, The Sinews of Power: War, Money, and the English State, 1688-1783 (London, 1989); Anne L. Murphy, The Origins of English Financial Markets: Investment and Speculation before the South Sea Bubble (Cambridge, 2009); Carl Wennerlind, Casualties of Credit: The English Financial Revolution, 1620-1720 (Cambridge, Mass., 2011).

There are a variety of technical labels for such discounting techniques in modern business and accounting practices, notably "net present value" (NPV) and "discounted cash flow" (DCF). For overviews of the history and significance of exponential discounting techniques, see R. H. Parker, "Discounted Cash Flow in Historical Perspective," J. Account. Res. 6 (1968): 58-71; Scott P. Dulman, "The Development of Discounted Cash Flow Techniques in U.S. Industry," Bus. Hist. Rev. 63 (1989): 555-87; Liliana Doganova, "Décompter le Futur: La Formule des Flux Actualisés et le ManagerInvestisseur," Soc. Contemp. 93 (2014): 67-87. On climate change and discounting, see David Weisbach and Cass R. Sunstein, "Climate Change and Discounting the Future: A Guide for the Perplexed," Yale Law Policy Rev. 27 (2009): 433-57.
} 
capitalist infrastructures that those practitioners who used it would never question it and most lay people would never know of its critical importance. ${ }^{6}$ In the late seventeenth and early eighteenth centuries, though, things were far less settled. The black box had not yet been closed. Alongside compound-interest discounting, Royal Society calculators explored an array of substantially different approaches to the mathematics of financial time. Many of the mathematical excursions carried out by the likes of John Collins and Thomas Watkins did not necessarily get very far and left only limited marks on the development of mathematical research or financial practice. They make for an admittedly abstruse topic for historical research - even within fields like the history of mathematics and the history of accounting, which have high thresholds for technical indulgence. But, I want to suggest, these kinds of technical sources are also remarkably useful sources for studying the history of capitalism. By digging into the technical details of these exploratory calculations, we can glimpse early modern people wrestling with profound questions about value, time, and the future while those questions were still up for grabs. ${ }^{7}$ By allowing us to think alongside earlier actors for whom the economic future might have unfolded very differently, these calculations help us to denaturalize an essential piece of capitalism's code.

One of the most striking trends in recent historical and social scientific scholarship on both capitalism and science and technology has been a recognition that "the future matters" - that is, that people's attitudes, aspirations, and images of future time have a profound impact on life in the present. ${ }^{8}$ In a sweeping new book, economic sociologist Jens Beckert has argued that capitalism is effectively defined by a particular, forward-looking temporality: "Capitalism is a system in which actors - be they firms, entrepreneurs, investors, employees, or consumers - orient their activities toward a future they perceive as open and uncertain." In his account, people are pulled into economic action — buying, investing, learning, working, consuming — by their imagination, by their sense that acting will produce some (better) expected future. This "temporal disposition" is "crucial to understanding ... how capitalism diverges from the economic orders that preceded it." Scholars in STS have made a similar observation, stressing that "imaginaries" of the future play a critical role in motivating and organizing scientific and technical enterprise. ${ }^{10}$ Scholars of modern science and modern capitalism observe that, in both domains, the future can become a crucial site of

\footnotetext{
${ }^{6}$ On "black boxes," see the classic statement by Bruno Latour, Science in Action: How to Follow Scientists and Engineers through Society (Cambridge, Mass., 1987).

${ }^{7}$ For further discussion of "financial quantification conventions" and capitalism, see Eve Chiapello and Christian Walter, "The Three Ages of Financial Quantification: A Conventionalist Approach to the Financiers' Metrology," Hist. Soc. Res./Hist. Sozialforsch. 41 (2016): 155-77, esp. 161.

${ }^{8}$ On recent historiographical interest in the "future," see Susan Friend Harding and Daniel Rosenberg, Histories of the Future (Durham, N.C., 2005); David C. Engerman, "Introduction: Histories of the Future and the Futures of History," Amer. Hist. Rev. 117 (2012): 1402-10, and other papers in the forum. Note also the workshop "Histories of the Future," convened at Princeton University by Fred Gibbs, Erika Lorraine Milam, and Joanna Radin, 6-7 February 2015. Papers from that event can be found at histscifi.com (accessed 16 April 2018).

9 Jens Beckert, Imagined Futures: Fictional Expectations and Capitalist Dvnamics (Cambridge, Mass., 2016), 1-2.

${ }^{10}$ George E. Marcus, ed., Technoscientific Imaginaries: Conversations, Profiles, and Memoirs (Chicago, 1995); Sheila Jasanoff and Sang-Hyun Kim, "Containing the Atom: Sociotechnical Imaginaries and Nuclear Power in the United States and South Korea," Minerva 47 (2009): 119-46; Jasanoff and Kim, eds., Dreamscapes of Modernity: Sociotechnical Imaginaries and the Fabrication of Power (Chicago, 2015).
} 
political conflict in the present as well. In his study of scientific and technical "visioneers" in the 1970s and 1980s, Patrick McCray writes that "creating visions of the future and the technologies that might help shape it is a political act as well as an exercise of imagination. But," McCray observes, "the future is not a neutral space." ${ }^{11}$ As Beckert explains, "to have power means: My expectations count!"12

This suggests that, in reconstructing the development of both capitalism and science, historians ought to attend closely to the practices of future construction and to changing orientations toward the future in the past. In particular, we ought to identify and examine moments when some aspect of the relationship between present and future came into question, and to examine the practices and interests through which those temporal contests were conducted. I contend that the quirky computational excursions of our Royal Society mathematicians - like the demonstrative business plan of Irénée Du Pont de Nemours, as described by Martin Giraudeau-constitute just such an archive for reconstructing contests over the future in the past. ${ }^{13}$

Early modern mathematicians like Collins and Watkins were not simply using calculation to make assessments about specific financial futures - to assess the value of a specific annuity or project the growth of a specific debt— but rather to explore an array of different kinds of futures, to imagine financial time itself in different ways. To be clear, those early modern mathematicians were not exactly concerned with predicting or speculating what the future might be. Indeed, outright claims to predict the future - particularly those that relied on mathematical calculations - were looked upon with suspicion by many during this period, seen to evoke the worst excesses of astrology. ${ }^{14}$ Rather, Collins, Watkins, and their mathematical colleagues were investigating what we might call the mechanics of the economic future, exploring different ways that future might unfold and how, according to those different mechanical models, the future rebounded upon the present. This different mode of futurity may seem unfamiliar to many readers, at once both stranger and less spectacular than the more fantastical "imaginaries" and "visioneering" that have attracted recent scholarly attention. Instead of projecting forward from the present to the future, they were dealing with calculations that traveled backward from the future to now, giving that future a value in the present moment. (Theirs was not the future tense, but the future perfect.) Yet in investigating these alternative future-to-present mechanics, they were forced to engage deep questions about future time itself - the trajectories along which it proceeded, the uncertainties it entailed, the ties of obligation that bound it to the present.

If futurity offers one crucial point of convergence for scholars of science and scholars of capitalism, so too does calculation. Within economic sociology, in particular,

\footnotetext{
${ }^{11}$ W. Patrick McCray, The Visioneers: How a Group of Elite Scientists Pursued Space Colonies, Nanotechnologies, and a Limitless Future (Princeton, N.J., 2013), 16.

${ }_{12}$ Beckert, Imagined Futures (cit. n. 9), 80.

${ }^{13}$ Martin Giraudeau, "Proving Future Profit: Business Plans as Demonstration Devices," in this volume.

${ }^{14}$ On changing ideas about prediction in the early modern period, and suspicions of calculative predictions in particular, see Edward M. Jennings, "The Consequences of Prediction," Stud. Voltaire 18th Cent. 153 (1976): 1131-50; Will Slauter, "Forward-Looking Statements: News and Speculation in the Age of the American Revolution," J.Mod. Hist. 81 (2009): 759-92; Benjamin Wardhaugh, Poor Robin's Prophecies: A Curious Almanac, and the Everyday Mathematics of Georgian Britain (Oxford, 2012). I discuss these themes further in Deringer, Calculated Values: Finance, Politics, and the Quantitative Age (Cambridge, Mass., 2018), chap. 6.
} 
there has been a flurry of new thinking about how best to conceptualize the role that calculations play in ordering economic life. The most provocative assertion has been the claim that economic calculations are performative, having the power to change economic circumstances and - in exceptional cases - to create the conditions of their own truth. ${ }^{15}$ Yet this claim has attracted a wide array of critiques. In his Imagined Futures, Beckert offers a particularly creative riposte to this performativity thesis, arguing that capitalism's fictional futures are ultimately narrated, not calculated, and suggesting that economic calculations are ultimately just "props" that assist actors in this narrative process. ${ }^{16}$

The story told here suggests that calculations may also serve a very different, overlooked function in the dramas of economic life: calculations can be the very medium through which economic imagination happens. To modern eyes, the notion that calculation might be imaginative, or imagination calculative, may feel peculiar, as the two are often made out to be essentially antithetical. But those two modes of thinking have not always seemed so distant from one another. For early modern Europeans, they seemed rather closer in spirit, both essential capacities of an intelligent, reasonable, and indeed scientific mind. The work of Lorraine Daston suggests that it was in the late eighteenth and especially the nineteenth centuries when the two began to take on starkly different characters: calculation, once "allied with the higher mental faculties of speculative reason and moral judgment," came to seem mechanical, laborious, and uninspiring, albeit objective; imagination, once seen to be "essential to philosophy and science - the pursuits of reason," became a subjective threat to the impersonal objectivity expected of scientists. ${ }^{17}$

This essay reveals that, for early modern thinkers confronting the new timescapes opened up by their ongoing "Financial Revolution," calculation was crucially imaginative. It shows that broader political-economic visions are forged and fought out through the details of calculative practice - as can also be seen elsewhere in this volume, in Giraudeau's study of novel techniques for "proving financial profit" in France at the dawn of the nineteenth century, and in Arunabh Ghosh's account of Soviet and Chinese scientists' quest to formulate a "socialist, scientific, and correct" mode of statistical practice that corrected the ills of "bourgeois statistics." ${ }^{18}$ Calculations themselves can be evocative, generating alternative scenarios, evoking new futures, playing out contests over different values. As anthropologist Jane Guyer and others have recently observed, numbers can constitute an "inventive frontier." ${ }^{19}$ In seeking to un-

\footnotetext{
${ }^{15}$ On the performativity thesis, see Michel Callon, "Introduction: The Embeddedness of Economic Markets in Economics," in The Laws of the Markets (Oxford, 1998), 1-57; Donald MacKenzie, An Engine, Not a Camera: How Financial Models Shape Markets (Cambridge, Mass., 2006); MacKenzie, Fabien Muniesa, and Lucia Siu, eds., Do Economists Make Markets? On the Performativity of Economics (Princeton, N.J., 2007), esp. the essays by Callon, "What Does It Mean to Say Economics Is Performative?," 311-57, and Philip Mirowski and Edward Nik-Khah, "Markets Made Flesh: Performativity, and a Problem in Science Studies, Augmented with Consideration of the FCC Auctions," 190-224 (for a notable critique of performativity); Franck Cochoy, Martin Giraudeau, and Liz McFall, "Performativity, Economics, and Politics: An Overview," J. Cult. Econ. 3 (2010): 139-46.

${ }_{16}$ Beckert, Imagined Futures (cit. n. 9), 68.

${ }^{17}$ Lorraine Daston, "Enlightenment Calculations," Crit. Inq. 21 (1994): 182-202, on 185; Daston, "Fear and Loathing of the Imagination in Science," Daedelus 134 (2005): 16-30, on 20.

${ }^{18}$ Giraudeau, "Proving Future Profit" (cit. n. 13); Arunabh Ghosh, "Lies, Damned Lies, and (Bourgeois) Statistics: Ascertaining Social Fact in Midcentury China and the Soviet Union," in this volume.

19 Jane Guyer et al., "Introduction: Number as Inventive Frontier," Anthropol. Theorv 10 (2010): 36-61.
} 
derstand how capitalism's future unfolded in the past, scholars would be well served to look at such calculations. This is a task for which historians of science seem especially well equipped.

\section{COMPOUND INTEREST AND THE EXPONENTIAL FUTURE}

At the center of nearly all financial practices - borrowing, lending, mortgaging, investing, insuring - are translations of economic value across time, between the present and various points in the future. One of the essential objectives of financial calculation is, therefore, to organize these temporal translations and explain how value varies with time. A simple example is the calculation of "future value," namely, how much a given sum of money will be worth in the future. What will $£ 100$ today be worth in twenty years? Arguably even more fundamental to financial practice, though, is the reverse maneuver: moving from future to present instead of present to future. Imagine you will receive $£ 100$ in twenty years; what is that $£ 100$ worth today? What is the present value of that future sum? From these two basic problems - future value and present value - arise myriad more complicated cases. An especially important one is calculating the present value of a stream of regular payments made in the future, like an annuity that pays $£ 100$ per year every year for twenty years. Such streams of future payments arise in many situations, like the regular interest payments made on a bond or loan, the premium payments made on a life-insurance policy, or the rents tenants pay to their landlords. It is easy to concoct many more complex scenarios. What is the present value of a stream of payments that continues indefinitely (a "perpetuity")? How do you assess the value of an income stream that does not start paying until future time, like the value of a landed estate that will not be inherited for a decade?

Over the last three centuries, there has emerged one paradigmatic approach to answering all of these questions. It relies on the logic of compound interest. While there is a certain risk in beginning any historical account at the end point, it is worth laying out the basics of compound-interest discounting because it helps to put into perspective the alternative, imaginative options that mathematicians were exploring in the early modern period. Under the modern compound-interest paradigm, calculating future value involves calculating how much interest will accrue on your original principal, assuming that interest is paid at some fixed rate and that it compounds every year - namely, in each given year you earn interest not only on the principal but also on whatever interest has accrued. This assumes the future value of property grows exponentially. At 5 percent, that $£ 100$ will grow to a future value of $£ 265$ in twenty years, and to $£ 13,150$ in one hundred years. To calculate present values according to this method, simply reverse this procedure. The present value of $£ 100$ in twenty years is however much you would have to save today to have $£ 100$ in twenty years, assuming you earn compound interest in the interim. Again assuming 5 percent, the present value of $£ 100$ twenty years out is $£ 37.69$; one hundred years out, $£ 0.76$. Using compound-interest discounting, the standard formulas for future value $(F V)$ and present value $(P V)$ of a principal sum $p$ are as follows, where $r$ is the interest rate, and $t$ the time elapsed:

$$
F V(p)=p(1+r)^{t}
$$




$$
P V(p)=\frac{p}{(1+r)^{t}}
$$

Compound-interest discounting has some felicitous mathematical features, and some very peculiar ones. The exponential properties of compound interest are quite useful when dealing with streams of future payments. Consider, for example, an annuity that pays $£ 100$ every year for twenty years. Determining the present value of that entire annuity requires summing the present value of $£ 100$ at sequential points in the future $£ 100$ in one year plus $£ 100$ in two years ... plus $£ 100$ in twenty years. If compoundinterest discounting is used, this sum produces a geometric series, which is easy to handle mathematically. ${ }^{20}$ Assuming 5 percent interest, the annuity of $£ 100$ per year for twenty years is worth $£ 1,246$. This is the amount you would need to invest today to have $£ 100$ in one year (£95.24), plus the amount you would need to invest today to have $£ 100$ in two years (£90.70), plus the amount you would need to have $£ 100$ in three years (£86.38), and so on, all the way until the amount you would need to invest today to have $£ 100$ in twenty years $(£ 37.69)$ : $£ 1,246$ in total. A similar annuity for fifty years has a present value of $£ 1,826$; for one hundred years, the present value is $£ 1,985$. This same method can be applied even if the income stream is a perpetuity, which pays out forever. According to compound-interest discounting, a perpetuity that pays out $£ 100$ per year forever has a finite value: $£ 2,000$ (assuming 5 percent interest). This is not all that large a number, especially given that a comparable annuity for 100 years is worth almost as much, £1,985 - meaning that all of the payments that come after year 100 are worth a grand total of $£ 15$ today. In a sense, the logic of compound interest places a remarkably low value on the distant future. Because even very small sums are envisioned to grow incredibly vast in future centuries, that means that even incredibly vast sums in the future - when discounted back to the present —amount to very small sums today.

The history of compound-interest discounting in the European world is often said to begin with the Pisan mathematician Fibonacci. In his 1202 Liber Abaci ("Book of the Abacus"), Fibonacci explained how to calculate future values and present values by comparing the accumulation of interest to the way a merchant compounded profits on sequential trips between trading posts. ${ }^{21}$ Compound-interest techniques were reproduced and elaborated by Italian and French mathematicians over the ensuing centuries. In 1582, Flemish mathematician Simon Stevin published practical tables for calculating present-value problems by compound-interest discounting. ${ }^{22}$ Those techniques soon made their way to England, where multiple texts on compound-interest mathematics appeared in the early seventeenth century. Texts like Richard Witt's Arithmeticall Questions (1613) and William Purser's Compound Interest and Annuities (1634) stressed that compound-interest discounting could be used in an array of

\footnotetext{
${ }^{20}$ See table 1.

${ }^{21}$ William N. Goetzmann, "Fibonacci and the Financial Revolution," in The Origins of Value: The Financial Innovations That Created Modern Capital Markets, ed. William N. Goetzmann and K. Geert Rouwenhorst (Oxford, 2005), 123-44.

${ }^{22}$ On the early history of compound interest calculations, see Frank Swetz, Capitalism and Arithmetic: The New Math of the 15th Century (La Salle, Ill., 1987); G. W. Smith, "A Brief History of Interest Calculations," J. Indust. Eng. 18 (1967): 569-74; Michael E. Scorgie, "Evolution of the Application of Present Value to Valuation of Non-Monetary Resources," Accounting Bus. Res. 26 (1996): 237-48; Geoffrey Poitras, The Early History of Financial Economics, 1478-1776: From Commercial Arithmetic to Life Annuities and Joint Stocks (Cheltenham, 2000), chap. 5.
} 
applications, including valuing landed property. ${ }^{23}$ Therefore, the technical foundations of compound-interest calculation were well established by the middle of the seventeenth century, when our story begins. But those same calculations had not yet become authoritative in the way they later would. It is all too easy to tell a progressive, linear narrative about the triumph of compound-interest thinking that runs from Fibonacci to the present. The story was not so straightforward.

\section{JOHN COLLINS AND HIS CORRESPONDENTS EXPLORE DIFFERENT FUTURES, CA. 1665-85}

In seventeenth-century England, the most intrepid explorer of mathematical futures was John Collins. Born to a poor minister near Oxford in 1625, Collins was orphaned early and then parlayed a limited grammar school education into an apprenticeship to a bookseller, a position as clerk in the royal kitchen, and then seven years as purser on a merchant ship trading to Venice. Upon returning to London in 1649, Collins set himself up as a mathematics instructor and subsequently pursued a variety of unstable clerical positions within the inchoate administrative state. ${ }^{24}$ His greatest passion was for mathematical learning. His interests were remarkably ecumenical, ranging from basic arithmetical pedagogy, to practical concerns like navigation and barrel gauging, to esoteric questions about logarithmic spirals and the "quadrature" of curves. Beginning in the early $1650 \mathrm{~s}$, Collins published a collection of texts on practical mathematical topics, including accounting, "dialing" (the mathematics of sundials), and surveying. ${ }^{25} \mathrm{He}$ also became Restoration England's most prominent mathematical "intelligencer," dubbed by contemporaries as the "English Mersenne." ${ }^{\prime 26} \mathrm{He}$ built and maintained an extensive network of mathematical correspondents, spanning the British Isles and the Continent, which included John Wallis, Isaac Barrow, and John Flamsteed - not to mention Newton and Leibniz. ${ }^{27}$ (His correspondence with the latter two was later used by Newton's Royal Society champions as evidence of Newton's priority in inventing calculus.) Collins actively steered correspondents toward prob-

${ }^{23} \mathrm{R}[\mathrm{ichard}] \mathrm{W}$ [itt], Arithmeticall Questions: Touching the Buying or Exchange of Annuities . . . (London, 1613); William Purser, Compound Interest and Annuities. The Grounds and Proportions Thereof, with Tables to Divers Rates Most Usuall . . . (London, 1634). See also C. G. Lewin, "An Early Book on Compound Interest: Richard Witt's Arithmeticall Questions," J. Inst. Actuaries 96 (1970): 121-32; Lewin, "Compound Interest in the Eighteenth Century," J. Inst. Actuaries 108 (1981): 423-42, esp. 423-8.

${ }^{24}$ On Collins's biography, see D. T. Whiteside, "Collins, John," in Complete Dictionary of Scientific Biography, vol. 3 (Detroit, 2008), 348-9; William Letwin, The Origins of Scientific Economics: English Economic Thought, 1660-1776 (London, 1963), chap. 4; Pycior, Symbols (cit. n. 2), chap. 3.

${ }_{25}$ Representative works include John Collins, Introduction to Merchants-Accompts: Containing Seven Distinct Questions or Accompts, new ed. (1652; London, 1675); Collins, Geometricall Dyalling: or, Dyalling Performed by a Line of Chords Onely, or by the Plain Scale (London, 1659); Collins, The Doctrine Decimal Arithmetick, Simple Interest, \&c. (London, 1685).

${ }^{26}$ For a comparison to Mersenne, see Edward Sherburne, The Sphere of Marcus Manilius: Made an English Poem ... (London, 1675), 116-7.

${ }_{27}$ Much of Collins's correspondence is collected in Stephen P. Rigaud, ed., Correspondence of Scientific Men of the Seventeenth Century, 2 vols. (Oxford, 1841). On Collins's and related mathematical networks, see Jacqueline Stedall, "Tracing Mathematical Networks in Seventeenth-Century England," in The Oxford Handbook of the History of Mathematics, ed. Eleanor Robson and Jacqueline Stedall (Oxford, 2009), 133-52. On scientific correspondence networks during the early modern period, see David S. Lux and Harold J. Cook, "Closed Circles or Open Networks? Communicating at a Distance during the Scientific Revolution," Hist. Sci. 36 (1998): 179-211; Justin Grosslight, "Small Skills, Big Networks: Marin Mersenne as Mathematical Intelligencer," Hist. Sci. 51 (2013): 337-74. 
lems and encouraged members of their network to publicize their work, often helping them to navigate the complexities of the mathematical publishing trade. Collins was recognized for his contributions to mathematics in 1667 , when he was elected to the Royal Society of London, the first fellow to be absolved of paying dues. ${ }^{28}$

Collins made his career at the junction of learning and commerce, and the mathematics of financial time was a crucial thread uniting his varied enterprises. Collins wrote a collection of texts on financial mathematics himself and also urged members of his mathematical network to investigate questions that he had identified as having financial applications. One of his greatest interests, for example, was the mathematics of calculation itself - how to make certain common numerical calculations easier and the theoretical possibilities of certain calculative tools. This was evident in his interest in logarithms, developed earlier in the century by British mathematicians John Napier and Henry Briggs. As a practical matter, his posthumously published textbook, The Doctrine Decimal Arithmetick, Simple Interest, \&c. As Also of Compound Interest and Annuities (1685), was one of the earliest texts to make clear that many financial calculations, particularly those related to compound interest, could be understood as applications of the mathematics of logarithms and thus solved using $\log$ tables. ${ }^{29}$ Collins also had a keen interest in exploring the theoretical possibilities of what could be done using numerical tables. In the late 1660s and early $1670 \mathrm{~s}$, for example, Collins "pestered" the likes of Isaac Newton and James Gregory about whether it might be feasible to approximate the solution to any algebraic equation using just a small selection of tables. ${ }^{30}$

At times, Collins posed financial problems directly to his mathematical correspondents. We have already seen how Collins had communicated with Isaac Newton about the problem of "yield approximation," a question he also posed to James Gregory, Regius Professor of Mathematics at St. Andrews. ${ }^{31}$ Collins's interest in the yield approximation problem may have been piqued by one of his lesser-known correspondents, a tobacco cutter named Michael Dary. An amateur mathematician and "philomath" like Collins, Dary had a great interest in applying mathematical research to practical computational problems. Dary's 1677 Interest Epitomized, both Compound and Simple was among the era's most mathematically sophisticated financial texts. It used "symbolical" techniques and drew upon algebraic research by John Wallis to put the mathematics of interest on a sounder mathematical footing. Dary ultimately de-

\footnotetext{
${ }^{28}$ Michael Hunter, The Royal Society and Its Fellows, 1660-1700: The Morphology of a Scientific Institution (Chalfont St. Giles, Buckinghamshire, England, 1982) 8, 77.

${ }^{29}$ Collins, Doctrine Decimal Arithmetick (cit. n. 25), 8-14. See also "Collins/John," in "Birch's Biographical Notes,” British Library Add. MS 4,221, fols. 331-9, esp. fols. 333-4, 336. On logarithms and practical financial calculations, see Timothy Alborn, Regulated Lives: Life Insurance and British Society, 1800-1914 (Toronto, 2009), 121-7.

${ }^{30}$ H. W. Turnbull, The Correspondence of Isaac Newton, vol. 1, 1661-1675 (Cambridge, 1959), 5, 23n13; James Gregory to Collins, 23 November 1670, in Turnbull, Correspondence of Isaac Newton, 45; Gregory to Collins, 15 February 1671, in Turnbull, Correspondence of Isaac Newton, 61; Collins to Francis Vernon, n.d. (1671?), Letter LIX, in Rigaud, Correspondence of Scientific Men (cit. n. 27), $1: 155-8$, on 156 .

${ }^{31}$ Gregory to Collins, 2 April 1674, Letter CCXIV, in Rigaud, Correspondence of Scientific Men (cit. n. 27), 2:255-6. On the history of this problem, see Augustus de Morgan, "On the Determination of the Rate of Interest of an Annuity," Assurance Magazine, and Journal of the Institute of Actuaries 8 (1859): 61-7; Gabriel A. Hawawini and Ashok Vora, "Yield Approximations: A Historical Perspective," J. Finance 37 (1982): 145-56.
} 
Table 1. Comparison of Formulas for Present and Future Values according to Compound and Simple Interest, Where $\mathrm{p}$ Is the Principal, $\mathrm{r}$ Is the Interest Rate, and $\mathrm{t} I$ S Elapsed Time

\begin{tabular}{lcc}
\hline & Compound interest & Simple interest \\
\hline $\begin{array}{l}\text { Future value of a sum } p \\
\text { Present value of a single sum } p\end{array}$ & $p(1+r)^{t}$ & $p(1+r t)$ \\
$\begin{array}{l}\text { Present value of an annuity paying } p \\
\text { annually for } n \text { years }\end{array}$ & $\frac{p}{(1+r)^{t}}$ & $\frac{p}{1+r t}$ \\
\hline
\end{tabular}

veloped his own numerical technique for addressing the yield approximation problem, which he worked into his 1677 textbook. ${ }^{32}$

Such explorations into logarithmic calculation and annuity yields fell mostly within a compound-interest paradigm. But not all of the mathematical explorations by Collins and his collaborators did. They put at least as much effort into a significantly different approach: simple-interest discounting. Like the compound-interest approach, simple-interest discounting translates across time periods by assuming that steady interest is earned as time passes. Where the simple-interest approach differs concerns how that interest is earned. Simple interest does not assume "interest upon interest" like compound interest does. If $£ 100$ is set aside and earns 5 percent simple interest, the interest paid is just $£ 5$ every year, regardless of how much interest has already accrued. Simple interest grows linearly with time, not exponentially. In many ways, it is just as plausible to create a mathematics of time based on simple interest as compound interest. (See table 1.) Computing the present value of a single sum using the simple-interest approach is quite straightforward. The present value of $£ 100$ in twenty years is whatever you have to save today to have $£ 100$ in twenty years, assuming simple interest. Simple interest discounting seems to have been relatively common in commercial transactions in the seventeenth century, particularly for individual sums and short time periods. Contemporary guides to commercial calculations, like the popular Webster's Tables by William Webster, often foregrounded simple-interest techniques. ${ }^{33}$

The simple-interest approach to financial time posed one especially vexing mathematical problem, though: calculating the present value of annuities. As discussed, compound-interest reasoning made calculating the present value of annuities easy to manage because of the geometric series that arose. When simple-interest discounting was applied, though, the calculations proved much less tractable. In 1677, Dary cautioned that calculating present value according to simple interest "doth not hold but only in the payment of Single Sums, for when many equal payments are made at equal times it faltereth." ${ }^{\prime 34}$ Mathematically, adding up a stream of present values calculated using simple-interest discounting produced a harmonic series, or what con-

\footnotetext{
${ }^{32}$ Michael Dary, Interest Epitomized, both Compound and Simple (London, 1677), [ii], 1, 8. On Dary, see Stedall, "Tracing Mathematical Networks" (cit. n. 27), 148.

${ }_{33}$ See, e.g., William Webster, Webster's Tables for Simple Interest Direct, at 10, 8, 7, and 6 p. per Centum ... For Simple Interest to Rebate, at $8 l$. per Centum . . . , The Second Edition, with Very Large Additions (London, 1629).

${ }^{34}$ Dary, Interest Epitomized (cit. n. 32), [iii].
} 
temporaries termed a "musical" series. ${ }^{35}$ Unlike geometric series, whose sums could be easily computed using a single algebraic formula, early modern mathematicians were at a loss when it came to calculating the sum of a harmonic series - short of laboriously calculating each term and adding them all up. What is more, harmonic series behaved very differently than their geometric siblings. Most dramatically, harmonic series with an infinite number of terms never seemed to converge to a definite value, as geometric series did. ${ }^{36}$ This had profound implications for the valuation of perpetual streams of income, like land rents. If harmonic series always had infinite values, then perpetuities had infinite value according to the simple-interest approach.

Some seventeenth-century financial mathematicians were not willing to let the possibilities of simple-interest discounting go unexplored. For John Collins, finding a way to calculate the sum of harmonic series became a personal campaign. In 1668, for example, Collins wrote to Henry Oldenburg asking for the secretary's help in locating a recent book by Erasmus Bartholin, which Collins thought "perchance handles the Musicall Progression" and could thus help him "enlarge my Paper of interest." ${ }^{37}$ Not long thereafter, in January 1670, Collins posed the question of "how to find the aggregate of a series of fractions, whose numerators are the same, and their denominators in arithmetical progression" in his first exchange with Isaac Newton. Newton realized the problem had a broader mathematical appeal because it "much resembles the squaring of the hyperbola." ${ }^{38}$ In other words, the problem of simpleinterest discounting was closely related to that of finding the area underneath hyperbolic curves, a foundational problem in what would soon be recognizable as integral calculus. ${ }^{39}$ Collins queried other members of his network for insights on the harmonic series as well, including James Gregory. ${ }^{40}$ Collins explained his ongoing quest most clearly in a letter (ca. 1671) to Francis Vernon, a fellow "intelligencer," laying out in very deliberate terms how the "adding of a musicall progression" related to calculating the "present worth" of an annuity, as well as to finding the "area of the hyperbola." ${ }^{41}$

Despite his extensive solicitations, Collins struggled to make progress on the harmonic series problem. But he never seems to have given up on it. His posthumous Doctrine of Decimal Arithmetick, Simple Interest, \&c., published in 1685, began with a discussion of how to calculate future and present-value problems using simple interest, before acknowledging that work still had to be done to figure out how to de-

\footnotetext{
${ }^{35}$ A harmonic series contains fractions with fixed numerators, whose denominators form an arithmetic sequence, e.g., $\left(\frac{1}{1}+\frac{1}{2}+\frac{1}{3}+\frac{1}{4}\right)$ or $\left(\frac{3}{4}+\frac{3}{7}+\frac{3}{10}+\frac{3}{13}+\cdots\right)$.

${ }^{36}$ On the history of research on the harmonic series, see William Dunham, "The Bernoullis and the Harmonic Series (1689)," in Journey through Genius: The Great Theorems of Mathematics (New York, 1990), chap. 8.

${ }_{37}$ Collins to Henry Oldenburg, [? December] 1668, in The Correspondence of Henry Oldenburg, vol. 5, 1668-9, ed. and trans. A. Rupert Hall and Marie Boas Hall (Madison, Wis., 1968), 212.

${ }^{38}$ Newton to Collins, 19 January $1669 / 70$ (cit. n. 1); Collins to Newton, 13 July 1670, Letter CCXXX, in Rigaud, Correspondence of Scientific Men (cit. n. 27), 2:301-3; Newton to Collins, 20 July 1671, MS Add. 9597/2/18/11, Camb. UL.

${ }_{39}$ Summing the harmonic series involved finding closed solutions to infinite series of the form $\Sigma_{n} \frac{1}{a+b n}$, closely related to the problem of finding the area under hyperbolic curves of the form $y=\frac{1}{a+b x}$.

${ }^{40}$ James Gregory to Collins, 2 April 1674 (cit. n. 31), 2:2556, and 26 May 1675, Letter CCXVI, in Rigaud, Correspondence of Scientific Men (cit. n. 27), 2:259-62.

${ }^{41}$ Collins to Francis Vernon, n.d. [1671], Letter LIX, in Rigaud, Correspondence of Scientific Men (cit. n. 27), 1:155-8, on 155 .
} 
termine the present value of "an Annuity, at Simple Interest." Collins was optimistic that a solution was close at hand, though, possibly in a new text entitled "Arithmetical Quadratures," by the Bolognese mathematician Pietro Mengoli (1626-86). This was wishful thinking, it seems, as Collins admitted that Mengoli's was "a Book I never saw." 42

What is most significant in Collins's quixotic harmonic quest to find an effective mathematics of simple interest is not the progress he made - minimal at best — or how that quest became entangled with more elevated mathematical pursuits like integral calculus. Rather, most remarkable is what it reveals about the imaginative possibilities entertained in early modern financial thinking. Collins and his collaborators did not live in an economic world in which there was only one correct way to calculate the value of the future. They knew the basics of compound interest and its many extensions and wanted to explore its potential even further, yet they also imagined that there might be room for substantially different methods. This is not to say that these mathematicians looked upon all futures with equal favor. It is clear that Collins and others had some doubts about the validity and applicability of simple-interest discounting in certain scenarios, particularly when time horizons got long. ${ }^{43}$ At least once, in a letter to Vernon, Collins commented on the "absurdity of simple interest," in reference to his calculation that showed that a $£ 100$ annuity for 100 years was worth a hefty $£ 3,200$ at 6 percent interest, nearly double its value using compoundinterest discounting $(£ 1,662)$.

For Collins, the desire to extend simple-interest techniques may have been influenced by the contemporary legal environment. One commentator on Collins's achievements specifically noted his investigations into mathematical questions related to accounting for mortgages, observing that England's equity courts only allowed simple (not compound) interest to accrue to creditors under certain conditions in cases related to disputed mortgages. ${ }^{44}$ Such legal peculiarities reflected the complex place that charging financial interest had long held in English law. Due to the abhorrence of "usury" in the Christian tradition (and many other faith traditions), lending money at interest had been outlawed in England until 1545. From 1545 to 1552, and then from 1571 onward, this blanket prohibition was replaced by laws prohibiting lending above a certain maximum rate: first 10 percent, lowered to 8 percent in the $1620 \mathrm{~s}$, 6 percent by 1660 , and 5 percent in $1714 .{ }^{45}$ While lending at interest was widely practiced in seventeenth-century England, and many financial transactions - including those relating to annuities, bills of exchange, or real property - effectively involved the charging of interest in various indirect or disguised ways, there were still situations

\footnotetext{
${ }^{42}$ Collins, Doctrine Decimal Arithmetick (cit. n. 25), 7-8.

${ }^{43}$ Dary was especially harsh on simple-interest techniques, though perhaps because he favored the computational advantages afforded by the compound-interest approach; see Dary, Interest Epitomized (cit. n. 32), [iii]-[iv].

44 "Collins/John," in "Birch's Biographical Notes" (cit. n. 29), fol. 336.

${ }^{45}$ On the history of usury laws, and contemporary attitudes thereon during the period, see H. J. Habakkuk, "The Long-Term Rate of Interest and the Price of Land in the Seventeenth Century," Econ. Hist. Rev. n.s., 5 (1952): 26-45; Tim Keirn and Frank T. Melton, "Thomas Manley and the Rate-ofInterest Debate, 1668-1673," J. Brit. Stud. 29 (1990): 147-73; Peter Temin and Hans-Joachim Voth, "Interest Rate Restrictions in a Natural Experiment: Loan Allocations and the Change in the Usury Laws in 1714," Econ. J. 118 (2008): 743-58; Hugh Rockoff, "Prodigals and Projectors: An Economic History of Usury Laws in the United States from Colonial Times to 1900," in Human Capital and Institutions: A Long-Run View, ed. David Eltis, Frank D. Lewis, and Kenneth L. Sokoloff (Cambridge, 2009), 285-323.
} 
in which the specter of usury reared its head. This seems to have been particularly true in legal settings, where courts were on guard against practices that might be tantamount to usury (such as letting compound interest penalties rack up on a borrower who was delinquent in his mortgage payments). In such cases, compound interest appears to have been viewed with special wariness, compared to simple interest. One hypothesis is thus that the dubious status of compound interest in English law was a key factor driving Collins's preoccupation with exploring the mathematics of simple-interest discounting. Whatever the source of Collins's, and others', interest, though, and whichever way his own temporal preferences leaned, there is no doubt that he took very seriously the possibility of a very different kind of financial future - one in which the future was not devalued quite so heavily.

\section{THOMAS WATKINS CALCULATES SIX DIFFERENT FUTURES, 1715}

For John Collins and his correspondents in the later seventeenth century, their adventures into alternative futures remained exploratory, producing an array of minor insights and small problems, but not programmatic statements or transformative new techniques. A generation later, another commercially minded mathematician, or mathematically minded man of commerce, named Thomas Watkins would make a bolder statement. Most of what can be gleaned about Watkins's life emerges from records of his membership in the Royal Society of London. He was first elected in 1714, alongside the likes of J. T. Desaguliers and Pierre Varignon. One year later he produced a lone article in the society's Philosophical Transactions. A 1718 register of the society's membership listed Watkins as "Gent." and gave his address as St. Martin's Church-Court in the Strand. That same register suggests he played at least a modest part in the intellectual life of the society in the later 1710s. The register's author, Thomas Clark, employed a Greek letter code to indicate that certain fellows were the "most proper and able Persons to be consulted upon" any of ten fields - "Astronomy" $(\beta)$, "Chymistry" $(\eta)$, and so forth. Most fellows received no mark; President Newton got four $(\alpha, \beta, \gamma, \delta)$. Watkins merited an $\alpha$, for "Natural Philosophy and Mathematicks." The register notes that Watkins was also a member of the society's Council, alongside Newton, Edmund Halley, and future President Hans Sloane. ${ }^{46}$

As to Watkins's life outside the society, details are scarce, though like Collins it is clear he traveled between the worlds of business, publishing, and government service, as well as "Natural Philosophy and Mathematicks." In 1717, he published a practical pamphlet on financial mathematics, and that same year was appointed to a governmental post responsible for administering various lottery debts. ${ }^{47}$ Around 1724, Watkins and a collaborator published a short text describing "a scheme for making provision for the wives, children, or other relations" of army and naval officers. ${ }^{48}$ Based on his writings, he clearly had intricate knowledge of many areas of fi-

\footnotetext{
${ }^{46}$ [Thomas Clark], A List of the Royal Society of London; Instituted by His Majesty King Charles II. For the Advancement of Natural Knowledge . . . (London, 1718), 8-9, 13-4.

${ }^{47}$ Entry for 6 December 1717, Calendar of Treasury Books: Volume 31, 1717, ed. William A. Shaw and F. H. Slingsby (London, 1960), http://www.british-history.ac.uk/cal-treasury-books/vol31/pp698 -716 (accessed 22 May 2016).

${ }^{48}$ Thomas Watkins and Dan. Combes, An Abstract of a Scheme for Making Provision for the Wives, Children, or Other Relations of Such Officers. . ([London?], [1724]). As listed in the English Short Title Catalogue, estc.bl.uk (accessed 22 May 2016).
} 
nancial practice and some acquaintance with legal matters (though the absence of the professional designation "esq." suggests that he was not a lawyer).

Watkins's first, and only, publication in the Royal Society's Philosophical Transactions came in 1715: "Rules for Correcting the Usual Methods of Computing Amounts and Present Values, by Compound as well as Simple Interest; and of Stating Interest Accounts," signed "Thomas Watkins, Gent. F. R. S." 49 Superficially, the paper looked like many mathematical papers that occupied the Philosophical Transactions, with dense algebraic calculations in paragraph form, punctuated by the occasional table. Behind this formal style was a practical agenda. Watkins thought the standard financial calculations his contemporaries used were wrong because they relied on unrealistic assumptions and oversimplified mathematics. His goal was to correct those flawed techniques by offering more sophisticated models. Watkins broke down his proposed financial-computational reforms into three sections: "CompoundInterest," "Simple-Interest," and "Interest Accounts." The first two sections are particularly telling.

Watkins opened the first section, "Of Compound-Interest," with a bold assertion:

The Supposition whereon the Method of computing by Compound Interest is founded; viz. That all Interest Money, Rents, \&c. are or may be constantly receiv'd, and put out again at Interest, the Moment they become due, without any Charge, or Trouble, being impracticable; therefore all Computations by this method ... must needs be erroneous. ${ }^{50}$

In other words, Watkins believed that in most cases the logic of compound interest was an unrealistic way to think about value and time because it assumed the financial world worked much more smoothly than it actually did. In particular, those calculations implicitly assumed that investors would always be able to find good places to invest and reinvest their money, both in the present and the future, without any extra cost, delay, or uncertainty. This was hardly a trivial assumption. Capital markets were still in their relative adolescence. Real estate, either by purchasing land or extending mortgages, was a steady investment, but opportunities were not necessarily easy to find. Government bonds were still a new, somewhat unstandardized, and (many hoped) impermanent mode of investment; it would be the 1750s before Britons could count on government "Consol" bonds as a long-term, low-risk way to invest their money. In 1715, it invariably took time and effort to put money to work.

Watkins contended that this oversight had serious consequences. For one, it meant that usual compound interest calculations tended to overstate the future value to which a present sum would grow over time. (Watkins frequently called the future value "the Amount of a Sum of Money." $)^{51}$ It was simply too optimistic to pick a standard interest rate and assume that money would grow consistently at that rate. Conversely, this meant that the existing compound interest calculations understated the present value of future sums. Watkins's solution was to try to rebuild the apparatus of compound-interest calculation in a way that recognized the messiness of contemporary financial life. His first move was to introduce two new variables into existing compound-interest models. The first represented the annual "Charge and Trouble of

\footnotetext{
49 Thomas Watkins, "Rules for Correcting the Usual Methods of Computing Amounts and Present Values ....,"Phil. Trans. 29 (1715): 111-27.

${ }^{50}$ Ibid., 111.

${ }^{51}$ Ibid.; emphasis added.
} 
the Management" of one pound, which Watkins called $c$. The second variable, $t$, captured the wasted time "spent in receiving and putting [money] out again at Interest." 52 Algebraically, dealing with the first of these two issues was straightforward: Watkins deducted the charge for management "Trouble" from the interest rate to be received in a way that did not fundamentally change the structure of the calculations. (The rate $r$ became $r-c r=r(1-c)$, which Watkins renamed $d r$.) Dealing with the issue of wasted time was far more complicated. Watkins embarked on well over a page of intricate algebraic manipulations designed to build the inevitable time delays into the standard compound-interest calculations. As he did so, he defined a slew of new variables so that the symbolic bulk of his ever-growing formula would not get out of hand $\left(d\right.$ replaced $1-c, e$ replaced $1+d t r$, a Gothic-style $r$ replaced $\frac{d r}{e}$, etc.).

Watkins's algebra is exceedingly difficult to follow - at least for myself, and I suspect for many of Watkins's contemporaries. Yet Watkins seemed unconcerned that his calculations might appear inaccessible to readers. He thought that the challenge facing his computational reforms lay elsewhere. "The only difficulty that remains, is the right assuming the Quantities $c$ and $t$," he explained, "the impossibility of doing which with perfect Exactness, I suppose to be the reason why neither this, nor any Method of Correction to the like purpose, has yet been taken notice of." ${ }_{53}^{3}$ Such comments were indicative of the striking optimism that pervaded Watkins's paper. $\mathrm{He}$ seemed sincere in his hope that his arcane computational labors might change how his contemporaries went about their financial lives.

Watkins did not stop at applying his revised calculations to single sums. The most pivotal calculations were those involving annuities. He concluded his section "Of Compound-Interest" with a numerical "Specimen" of how his "corrected" methods could be applied to the valuation of annuities. He assumed $c$, the charge for management "Trouble," to be 6 percent, and he estimated $t$, the average amount of time lost in receiving and reinvesting sums, at four and a half months, or roughly three-eighths of a year. He produced a series of numerical tables giving the results of his revised interest calculations, showing both the future values ("Amounts") and present values of a $£ 1$ per year annuity. He surveyed a range of different interest rates (from 5 to 10 percent) and time horizons (for five to 100 years, plus perpetuities). In all of the tables he included a column showing the difference between the standard method of calculating these figures using compound interest and his own corrected method (fig. 1). ${ }^{54}$

Watkins's discussion "Of Simple-Interest," the subject of the second section of his paper, was even blunter. The author wasted no time pointing out the fundamental "absurdity of the Supposition, on which the usual Method of computing present Values by Simple-Interest, is founded." The key problem was that such simple-interest discounting assumed that any money received in the future, for example, from rents or an annuity, was always immediately reinvested ("put out again at Interest"), but interest earned on those sums was not, instead being allowed to "lie dead during the

\footnotetext{
${ }^{52}$ Ibid., 112.

53 Ibid., 114.

${ }^{54}$ Strangely, in analyzing annuities, Watkins's corrected method gave lower values than traditional compound interest calculations for both future values ("Amounts") and present values. This is odd given that he argued that, in general, traditional methods of compound interest undervalued the present value of single quantities. Watkins's explanation why, and his mathematical execution, is extremely difficult to follow on this point.
} 
Amounts of $\mathrm{I} l$.at 5 per Cent. computed 6 feveral Ways.

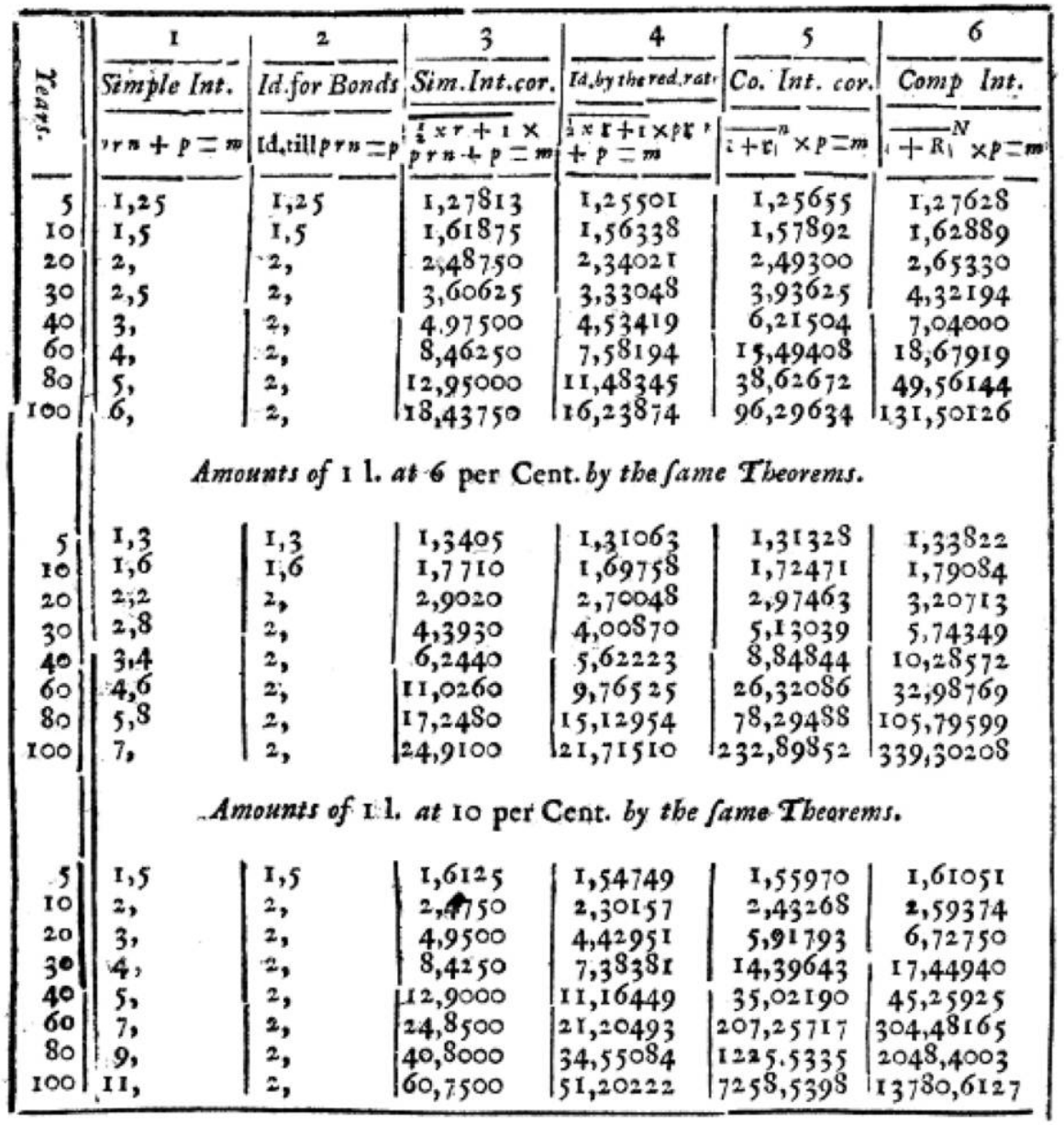

Figure 1. Image of Thomas Watkins's table, showing "Amounts of 11 . . . computed six several Ways." In Watkins, "Rules"(cit. n. 49), 120. Reproduced with kind permission of the Royal Society.

whole Term. " 55 Yet he acknowledged that certain circumstances demanded a simpleinterest approach, notably for legal reasons. British courts took an array of different views on the legality of financial interest - when it could be charged or demanded, how much, whether it could be compounded - based on the circumstances involved. For example, Watkins noted, the courts did not allow "Interest upon Interest" in disputes over debts; if a debtor failed to pay interest on a debt on schedule, the creditor was not allowed to penalize the debtor further by demanding interest on that unpaid interest. Watkins suggested that this was intended to "curb the Exorbitant Avarice of Usurers." (As noted above, for both moral and political-economic reasons, Britain's

${ }^{55}$ Watkins, "Rules" (cit. n. 49), 118. 
Table 2. The Future Value ("Amount") of $£ 1$ in 100 Years, 5 Percent Interest Rate, according to Watkins's Six Different Methods

\begin{tabular}{llr}
\hline Column & \multicolumn{1}{c}{ Method } & "Amount" (£) \\
\hline 1 & Simple interest & 6.00 \\
2 & Simple interest for bonds & 2.00 \\
3 & Simple interest corrected & 18.44 \\
4 & Simple interest corrected at the reduced rate & 16.24 \\
5 & Compound interest corrected & 96.30 \\
6 & Compound interest & 131.50 \\
\hline
\end{tabular}

Parliament had long imposed a maximum allowable interest rate, recently reduced from 6 to 5 percent in 1714.) Similarly, landlords could not charge tenants compounding interest on unpaid rents. ${ }^{56}$

Because of such legal vagaries, Watkins admitted that there might be situations in which a "corrected" approach to simple-interest discounting would be useful. He particularly felt that there were many situations in which it was logical, and legally permissible, to assume that interest would be earned upon interest one time but would not continue to compound beyond that - where interest-upon-interest was allowed, but interest-upon-interest-upon-interest was not. Watkins fashioned a formula calculating present values based on this intermediate approach, which he termed "Simple Interest corrected." Building on his work in the previous section, Watkins showed that it was also possible to further revise the "corrected" simple-interest formula by making the same adjustments he had made to the compound-interest formula, factoring in the cost of management and reinvestment delays. He dubbed this, his third new method, "Simple Interest corrected by the reduced rate."

Watkins summarized his models in two numerical tables that showed the results of his three new methods alongside traditional approaches. His first table (fig. 1) showed how to calculate the future value ("Amount") of $£ 1$ at 5, 6, and 10 percent interest rates, for terms ranging from five to 100 years, using six different methods: (1) standard simple interest; (2) simple interest for "Debts due by Bond" (a peculiar case where law limited the amount of total interest that could be charged to double the original principal); (3) Watkins's simple interest corrected; (4) his simple interest corrected "by the reduced rate"; (5) his compound interest corrected; and (6) standard compound interest. For example, in 100 years, £1 earning 5 percent interest would reach different "Amounts" depending on which of Watkins's six methods was used (table 2). Subsequently, a smaller table on the following page displayed the present value of a $£ 1$ annual annuity calculated according to simple interest corrected, compound interest corrected, and standard compound interest.

Watkins's remarkable tables mapped an array of different financial futures, ranging from the relatively limited growth entailed by simple interest to the explosive, exponential potential of compound interest. Watkins was most interested in exploring the possible futures that fell in between these two idealized extremes, the futures most likely to arise in the messy business of real life. Watkins did not feel the need to settle on one, superior calculation. He wanted to give options and even left open the pos-

${ }^{56}$ Ibid., 118-9. 
sibility that other formulas might need to be derived for new cases. A subsequent paragraph explained to readers the different scenarios in which it might make sense to use each of the six columns. For example, he explained that simple interest corrected (col. 3) "answers a Case of a Security or joynt Obligor that has duly and constantly paid the Interest, and at last the principal Sum of a Debt, from which he has a Counter-Bond from the principal Debtor." 57

Watkins's goal was not to obscure the intricacies of contemporary finance but to reveal them for the public using mathematics. He was fighting against his contemporaries' entrenched tendency to oversimplify and idealize. In closing, he urged readers not to object to his new "Rules and Theorems . . . merely because they tend to produce some Alteration in the present practice." Watkins looked forward to a future in which the expanding power of mathematics permitted a proliferation of more sophisticated calculations, each more sensitive to commercial realities. ${ }^{58}$

\section{BEFORE INTEREST BECAME UNINTERESTING}

As with John Collins's quest for a harmonic future based on simple interest, Thomas Watkins's attempt to create multiple calculating regimes did not seem to go very far. There seem to be no further references to Watkins's article in later editions of the Philosophical Transactions, and I know of no examples of Watkins's baroque formulas being put into use. What, then, do we make of these abortive excursions into alternative financial futures? First and foremost, they demonstrate that compoundinterest discounting was not an exclusive, uncontested, or inevitable way to think about the economic relationship of present and future. However indisputable and rational and natural that calculation seems in current practice, it was not always so. The question of how that black box got closed is a story that lies beyond the scope of this essay, but there is much to be learned by looking at what that box looked like before it was closed - by looking at the scattered computational components that were developed, tested, and thrown away. We learn that early modern thinkers had good reasons to believe that there was a place for simple interest, and that they were concerned that compound-interest models dangerously abstracted from the realities of commercial life. We also learn that early modern calculators, Watkins especially, were entertaining methods of financial calculation that were significantly more complicated mathematically than those that would eventually come to prevail - a reminder that the development of capitalism's logic cannot be told as a monotonic story about increasing "sophistication."

The example of these early Royal Society mathematicians demonstrates why, methodologically, historians of economic life can learn much from archives of scientific and technical practice. Scientific experimentation and technological design are often full of imagination and contestation, possibility and surprise. They are full of problems. They are excellent places to look for things, like the temporal logic of capitalism, that were problematic in the past but came to seem far less so with time. Our story of misbegotten quests to calculate alternative futures points the way toward new avenues for research in early modern economic practice and culture. Watkins's remarkable six-part taxonomy of different financial calculating regimes, for example,

${ }^{57}$ Ibid., 121.
${ }^{58}$ Ibid., 127. 
offers a veritable map of different economic value systems at work in early eighteenthcentury Britain, each operating with slightly different attitudes about value and time, fairness and obligation.

This essay has primarily told a story about a historical change that never occurred, about futures searched for but never quite found. To what degree can we say that the likes of Collins and Watkins were more directly part of the processes that shaped the economic logics that ultimately would prevail? As a coda, I will close with one suggestive story about Thomas Watkins. His alternative interest calculations did get mentioned in at least one other place, at least obliquely: his own next publishing effort, a 1717 Table of Redemption, dedicated to the House of Commons and signed "T. W. F. R. S." Like many such pamphlets of its time, Watkins's text was predominantly filled with tables to facilitate interest calculations. The entries in his tables were not monetary values, though, but times - specifically, the time it would take to pay down a fixed amount of debt (£100), depending on the interest rate the debt carried, the annual funds available for debt repayment, and the frequency with which payments were made. (For example, Watkins's table showed that, given a £100 debt bearing $4 \frac{1}{2}$ percent interest, and payments of $£ 9$ annually made half-yearly, it would take fifteen years, six months, and twenty-eight days to repay the debt entirely.) ${ }^{59}$

Watkins had a very specific application in mind for his tables. He wanted them to be used by "Parliamentary, or other Committees" who could use them to think through different fiscal policies "without adjourning themselves, or retarding their Conferences, for tedious Calculations." ${ }^{\prime 60}$ There was good reason to think demand for such a political tool would be high. Public debt was a tense issue at the time, as Parliament had racked up more than $£ 45$ million of debt in the course of two costly wars with France since 1688. There was widespread discussion about how best to handle these mounting burdens, and an array of inventive and sometimes outlandish plans for how to do so. Watkins was concerned about the proliferation of such "chimerical Projects of paying Debts without Mony" and hoped he could use his mathematical knowledge to help the nation's Parliamentary representatives navigate through them. ${ }^{61}$

What made these "redemption" calculations tricky was that, as the debt was paid down, interest continued to be paid, but that interest varied as the balance declined. Mathematically, computing how long it would take to redeem certain debts was a variant of the present-value problem. So which of his six different approaches to interestrate calculations did Watkins use? The answer: plain compound interest. For all his talk about the need for corrected methods in the Philosophical Transactions, he fell back upon the uncorrected methods when it came time to apply his expertise to public problems. To Watkins's credit, he did give an extensive explanation in the introduction to his Table explaining why he thought that particular method made sense for these specific circumstances - in other words, why "column 6"? ${ }^{62}$ But few readers probably realized that Watkins was even making such a choice.

\footnotetext{
59 "T. W. F. R. S." [Thomas Watkins], A Table of Redemption. Shewing at one View in What Time the Principal and Interest of any Debt from Three to Six per Cent. May Be Discharged. . . (London, 1717).

${ }^{60}$ Ibid., [3].

${ }^{61}$ Ibid., 5 .

${ }^{62}$ Ibid., [3].
} 
Here, perhaps, we can begin to see an even more fundamental way in which the histories of science and capitalism were entangled: namely, through the coproduction of forms of scientific expertise and objects of economic knowledge (and economic value). This is a theme that runs throughout several of the essays in this volume: for example, in Paul Lucier's study of the interactions between geological experts and corporate mining interests around the Comstock "lode" and in Victoria Lee's examination of the entwined emergence of fermentation science and industrial brewing in Meiji Japan. ${ }^{63}$ More specifically, the story told here is one of how scientific actors, in seeking to exercise influence over new fields of knowledge opened up by transformations in economic life, ended up pushing those fields in unanticipated directions, perhaps at odds with their own scientific judgments or those of their peers. In that sense, it parallels the story told by Lee Vinsel about psychologists in the early automobile age, who, in trying to make a place for themselves in the new field of auto safety through their expertise in mental testing, ended up reifying a vision of the "accident prone driver" that few in the psychological community endorsed. ${ }^{64}$

Just as he was experimenting with how to build new logics of financial calculation, Thomas Watkins was also experimenting with how to fashion his own role as a purveyor of knowledge, particularly with regard to a broader, interested "public." The same was true for John Collins. Both were intensely aware that calculating the relationship between present and future was a messy enterprise, fraught with ambiguities and imperfect assumptions. Yet what they presented to the broader public were predominantly simplified, ready-to-use calculations, based primarily on the logic of compound interest. They took on the task of interpreting the complications of the economic future for their fellow Britons, smoothing out the rough computational and conceptual edges. They left the hard problems to be solved behind closed doors by mathematicians. In attempting to fashion their own authority, they helped to make the very problems they were trying to solve seem less problematic than they knew them to be. They may have inadvertently helped to foreclose the very alternative futures they were investigating.

\footnotetext{
${ }^{63}$ Paul Lucier, "Comstock Capitalism: The Law, the Lode, and the Science"; Victoria Lee, "The Microbial Production of Expertise in Meiji Japan," both in this volume.

${ }^{64}$ Lee Vinsel, "'Safe Driving Depends on the Man at the Wheel': Psychologists and the Subject of Auto Safety, 1920-55," in this volume.
} 